\title{
О НАХОДКАХ ПЛАТИНОИДОВ В ПЕРВИЧНЫХ РУДАХ ЗОЛОТОСЕРЕБРЯНЫХ МЕСТОРОЖДЕНИЙ СЕВЕРНОЙ ЧУКОТКИ
}

\author{
В. Г.Сахно ${ }^{1}$, Ю. А. Кузнецов ${ }^{2}$, А. А. Дубков ${ }^{3}$, Е. В. Ненахова ${ }^{4}$ \\ ${ }^{1}$ Дальневосточный геологический институт ДВО РАН, Владивосток \\ ${ }^{2} \mathrm{AO}$ «Приморзолото», г. Москва \\ ${ }^{3}$ ВНИГНИ, г. Москва \\ ${ }^{4}$ ООО «ЦКИГ Цитрин», г. Воронеж
}

Поступила в редакцию 4 июля 2019 г.

\begin{abstract}
Аннотация: в статье приводятся результаты изучения руд, особенности минерального состава платиноидов, впервые обнаруженных в рудах месторождений Северной Чукотки - Купол, Двойное и Сентябрьское, которые относятся к золото-серебряному эпитермальному типу. Кроме наличия золота, серебра и теллура, характерного для этого типа руд, установлень значения содержания платиноидов. В совокупности с результатами исследований по Приморью, очевидно, что необходимо выделение единого многопрофильного Чукотско-Охотско-Восточно-СихотэАлинский трансрегионального вулкано-плутонического пояса, который заслуживает более детальных исследований на платиноиды.
\end{abstract}

Ключевые слова: золотосеребряные месторождения, платиноиды.

\section{ABOUT PLATINOID FINDINGS IN PRIMARY ROCKS OF GOLD-SILVER DEPOSITS OF NORTHER CHUKOTKA}

\begin{abstract}
: the paper presents the results of the study of ores and the features of the mineral composition of platinoids first discovered in ores of the deposits of Northern Chukotka: Kupol, Dvoynoye and Sentyabrskoye, which are of the gold-silver epithermal type. In addition to the presence of gold, silver, and tellurium, which is characteristic of this type of ore, the values of the platinum content are founded. In conjunction with the results of research in Primorye, it is obvious that it is necessary to single out a unified Chukotka-Okhotsk-East-Sikhote-Alin transregional volcanic-plutonic belt which deserves more detailed studies on platinoids.
\end{abstract}

Key words: goldsilver deposits, PGM.

Геологическое строение золото-сереброносных месторождений Северной Чукотки подробно освещено в многочисленных работах [1-14]. Большая часть этих работ касается вопросов золотосеребряной рудоносности этого региона. Рудные тела, по данным исследователей, относятся к золотосеребряному эпитермальному типу минерализации. Для Колымы известны работы, в которых описаны находки платиноидов в ассоциации с золотосеребряным рудопроявлением [5]. К этой категории относятся рудопроявления Наталкинское и Павлик, расположенные в пределах мезозоид к западу от центральной части ОхотскоЧукотского пояса [1]. Для Приморья в 2014-2016 гг. были опубликованы работы об особенностях золотосеребряного оруденения в рудопроявлениях южного Приморья (Милоградово и Глухое), в которых были обнаружены платиноиды $[10,15]$. Это позволило предположить, что такие же золотосеребряные месторождения, содержащие платиноиды в промышленных количествах могут быть и на Чукотке. Так как, восточная окраина Азии представляет собой единый вулкано-плутонический сегмент, состоящий из отдельных звеньев: Охотско-Чукотского, Восточно-Сихотэ-Алинского, Пусановского и Южно-Китайского. Формирование этих звеньев проходило в близком временном интервале: от позднего мела (альб) до позднего кайнозоя. Для этой протяженной структуры характерны также и общие черты развития магматизма и рудогенеза $[3,10,11]$.

Нами изучен материал из бороздовых проб золотосеребряных месторождений: Купол, Двойное, Сентябрьское. Рудные тела этих месторождений образованы малосульфидными кварц-адуляровыми жилами и зонами прожилкования в туфах верхнемелового 
возраста.

При исследовании руд этих трёх месторождений, с помощью методов электронной микроскопии, кроме наличия давно известной золотосеребряной минерализации и минеральных форм теллура, характерного для Двойного и Сентябрьского $[4,9]$, было зафиксировано наличие практически всех видов платиноидов. Первичные исследования руд, установившие данный факт, проводились на электронном микроскопе HITACHI TM-1000, рентгеноспектральный анализатор с энергодисперсионной системой (ЭДС) "SwiftED-TM EDS" (ВНИГНИ, аналитик Дубков А. Н.). На основании изучения снимков и результатов ЭДС, было предположено, что основная масса платиноидов (наряду с золотом и серебром) представлена в виде мельчайших пластиночек в доли микрона или первые микроны в сростках с рудными сульфидами или минералами алюмосиликатного состава, или на поверхности кристаллических форм (рис. 1). Иногда, на поверхности микротрещин вскрытых при дроблении породы, или в виде мельчайших (практически точечных) образований в составе сульфидов. Такое предположение (о наличии золота и ЭПГ), кроме полученных фотографий, основывается на том, что по данным ЭДС в ряде спектров отсутствует сера, но присутствуют: золото и ЭПГ. Чаще всего встречаются плёночные (практически двумерные) образования. Луч электронного микроскопа легко их «прошивает», проникая в алюмосиликатный матрикс, что и фиксируется электронно-дисперсионной системой микроскопа. Результаты этих исследований представлены в табл. 1.

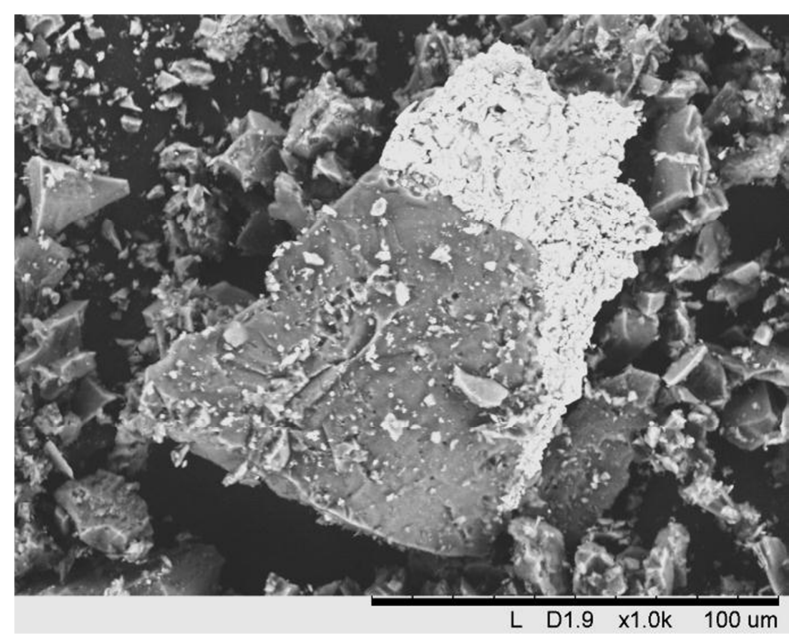

Puc. 1. Месторождение Купол. В поле зрения электронного микроскопа НІТАСНI ТМ-1000 обломки алюмосиликатной массы руд (серый оттенок). Светло серый оттенок характерен для рудного материала, с повышенным содержанием драгоценных металлов, который, в виде плёнки и отдельных частичек находится на гранях обломка. Данные ЭДС для этого снимка приведены в табл. 1 (месторождение Купол), строка с надписью Spectrum-17.

При анализе табл. 1 чётко видно, что помимо известных ранее элементов ( $\mathrm{Au}, \mathrm{Ag}, \mathrm{Te})$, неожиданно зафиксированы значимые содержания платиноидов. Интенсивность их сигнала, выраженная в весовых процентах, сопоставима с такими «маркирующими» для этих месторождений элементами как золото, серебро и теллур.

Для проверки полученных данных из этих же образцов проб, была (пропорционально массе имеющегося у нас материала), были выделены образцы тяжёлой фракции. Для месторождения Купол таких образцов тяжёлой фракции было получено - 5, для Двойного - 3, для Сентябрьского - 2 .

Они были изучены на электронном микроскопе Geol 6380LW с системой количественного энергодисперсионного анализа «Inca» в Воронежском госуниверситете (рис. 2, 3, 4). Его дисперсионная приставка менее совершенна, и считается, что в системе количественного энергодисперсионного анализа «Inca» возможно частичное и полное перекрытие спектром платины спектров других платиноидов. И это действительно, в большинстве случаев, так. Потому, что их химические свойства близки. Поэтому, на электронном микроскопе Geol 6380LW с системой количественного энергодисперсионного анализа «Inca» изучались только спектры платины. Положительными особенностями микроскопа Geol 6380LW по сравнению с НITACHI ТМ-1000 является возможность получить данные ЭДС практически в точке (3х3 микрона) и получить поэлементную карту для трёх элементов (рис. 5). Отрицательными качествами, по сравнению с НІТАСНІ ТМ-1000, является более низкая разрешающая способность, влияющая на качество изображения мелких частиц. Но на обоих типах микроскопов их спектральные характеристики находятся в диапазоне 1,5-2,4 кЭВ и не перекрываются соответствующими характеристиками других элементов.

Материал тяжёлой фракции, полученный из рудных зон, детально изучен под бинокулярным микроскопом. Он состоит, в основном, из пирита, галенита, и, отчасти - циркона (рис. 5).

Поэтому представлялось, что если результаты определений на более «грубой» ЭДС микроскопа Geol 6380LV подтвердят данные микроскопа HITACHI TM-1000, то это подтвердит, что платиноиды в рудах этих месторождений есть. Так же как и золото, и серебро, и теллур.

Исследования на электронном микроскопе Geol 6380LV подтвердили данные, полученные на электронном микроскопе НITACHI ТМ-1000, в минералах тяжелой фракции.

Применённая методика исследования на двух типах электронных микроскопов показала, что кроме золотосеребряной минерализации, как в макро - так и в наноформах, в рудах этих месторождений присутствуют наноразмерные выделения металлов платиновой группы. Установлено, что размеры этих выделений соответствуют группам из плёночных и одиночных образований состоящих из небольшого количества (первые десятки и сотни) атомов или молекул (рис. 5). 


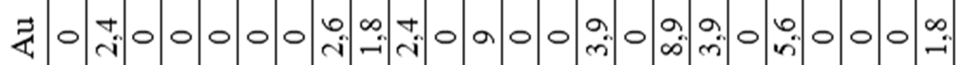

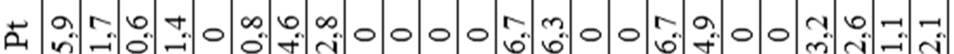
H

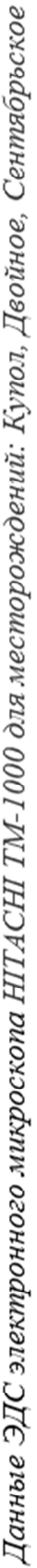

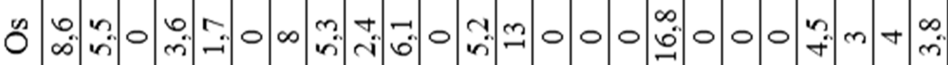

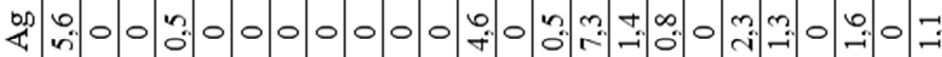$$
\text { 茥 ल. }
$$

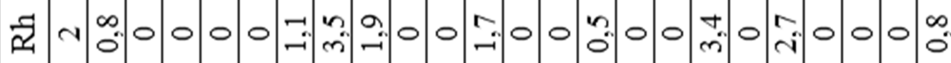

○ㄹ 袧

要

ए

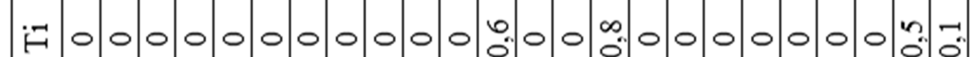

U. 0 o 0 m.

VA 1 人

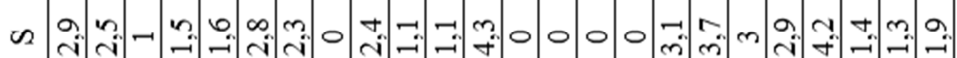

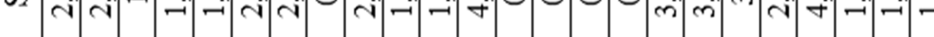

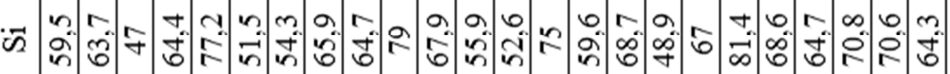

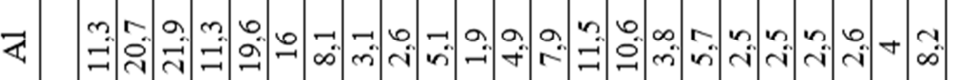

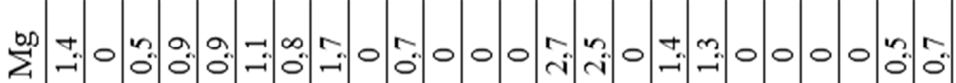

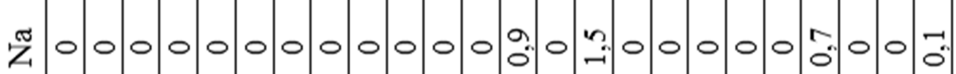

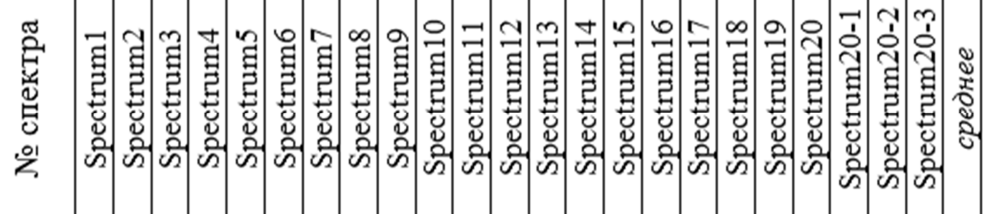

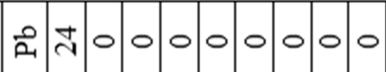

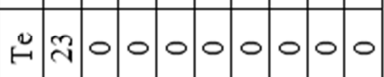
รี่

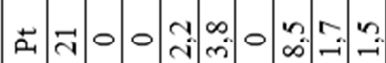
H. 0)

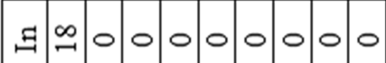

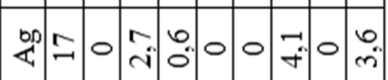
ت્ञ

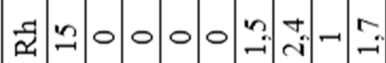

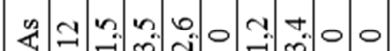
己 $=00000000$

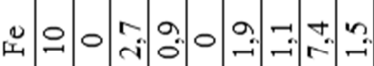
Ḧa

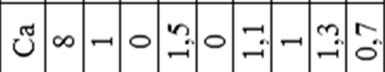

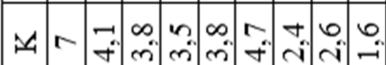
\begin{tabular}{ll|l|l|l|llll}
$n$ & 0 & 7 & 0 & $m$ & 4 & 4 & 0 & 0 \\
\hline
\end{tabular}

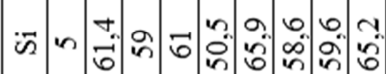

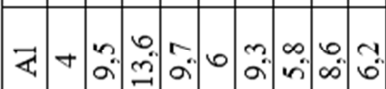

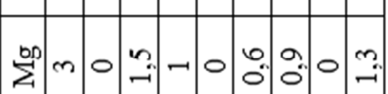

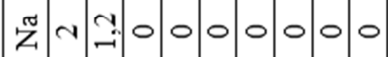
ㄱำชับ

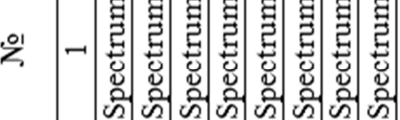


동

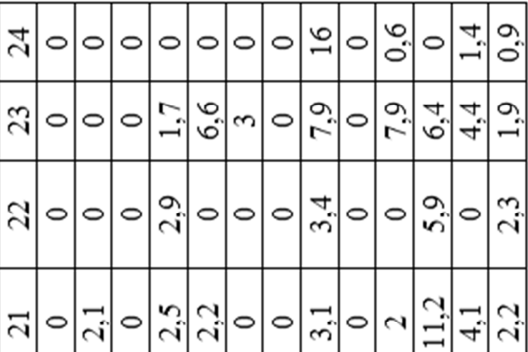
40

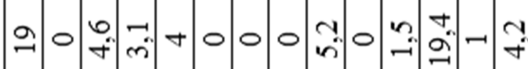

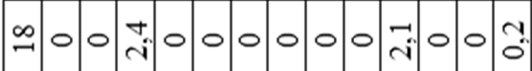

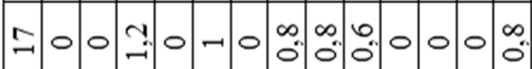
일

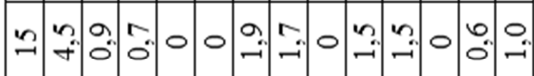
I

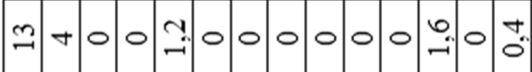
ง

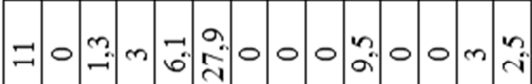

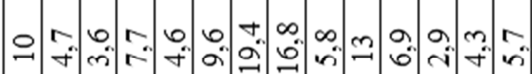

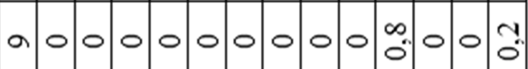

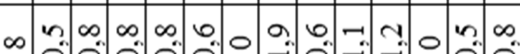

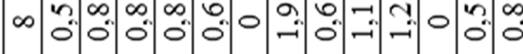

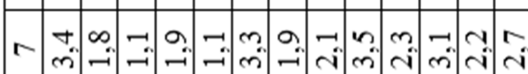

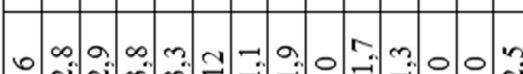

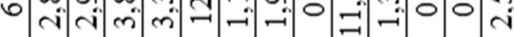

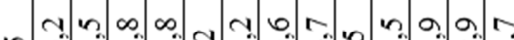

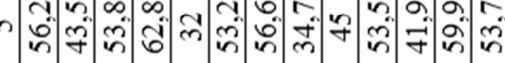

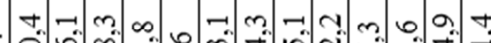

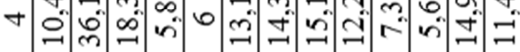

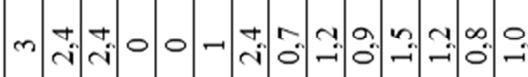

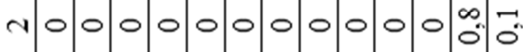
리르를 -

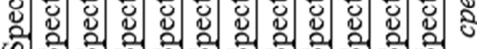
कें में में में में में में में

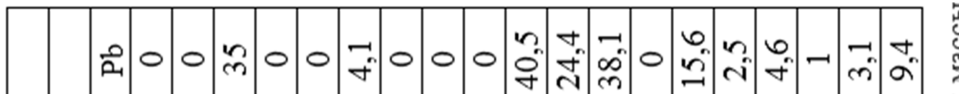

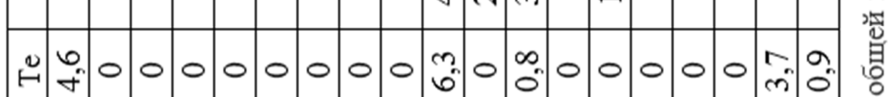

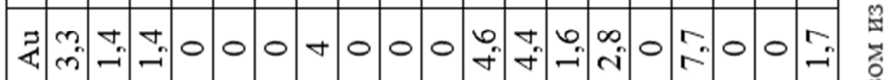

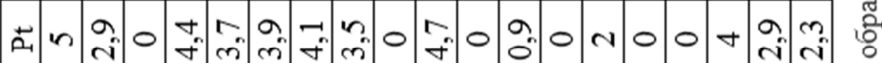
H D. m ت⿹ मี

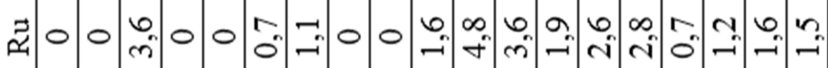
คํำ

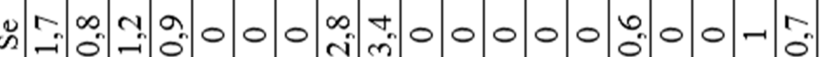
ส 至o 0 o

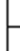

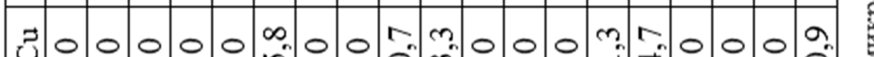

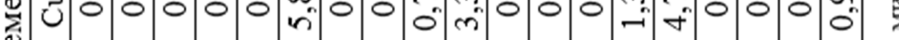

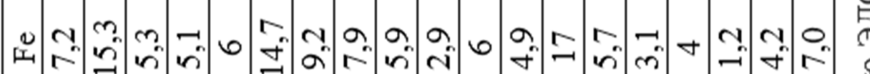

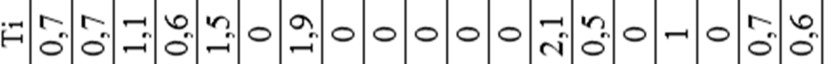

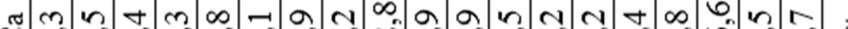

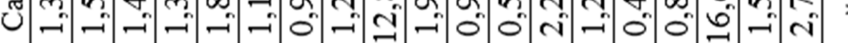

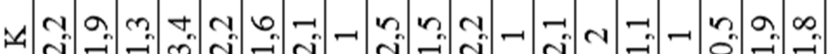
4.

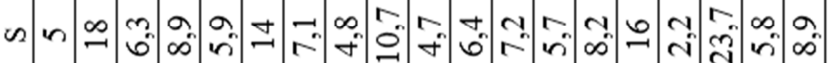

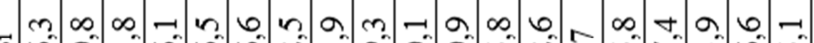

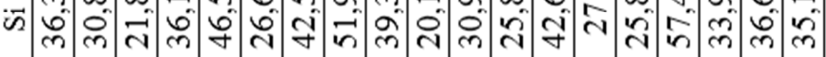

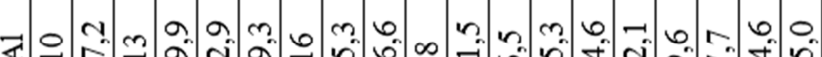

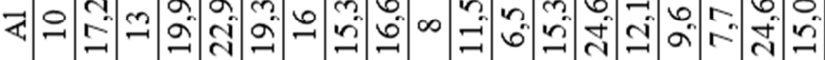

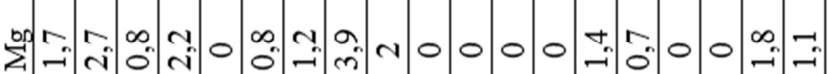

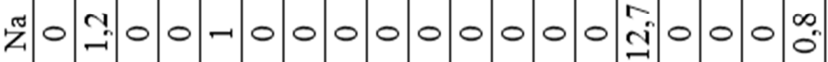

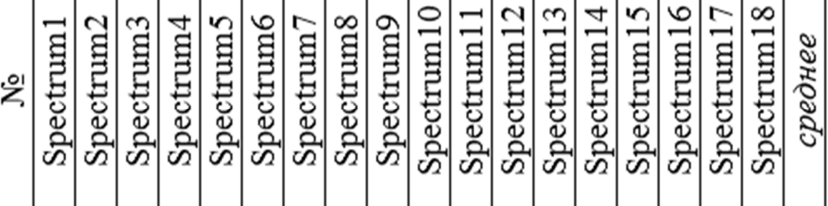
挋 䍃宫 צั่ 趂 년 

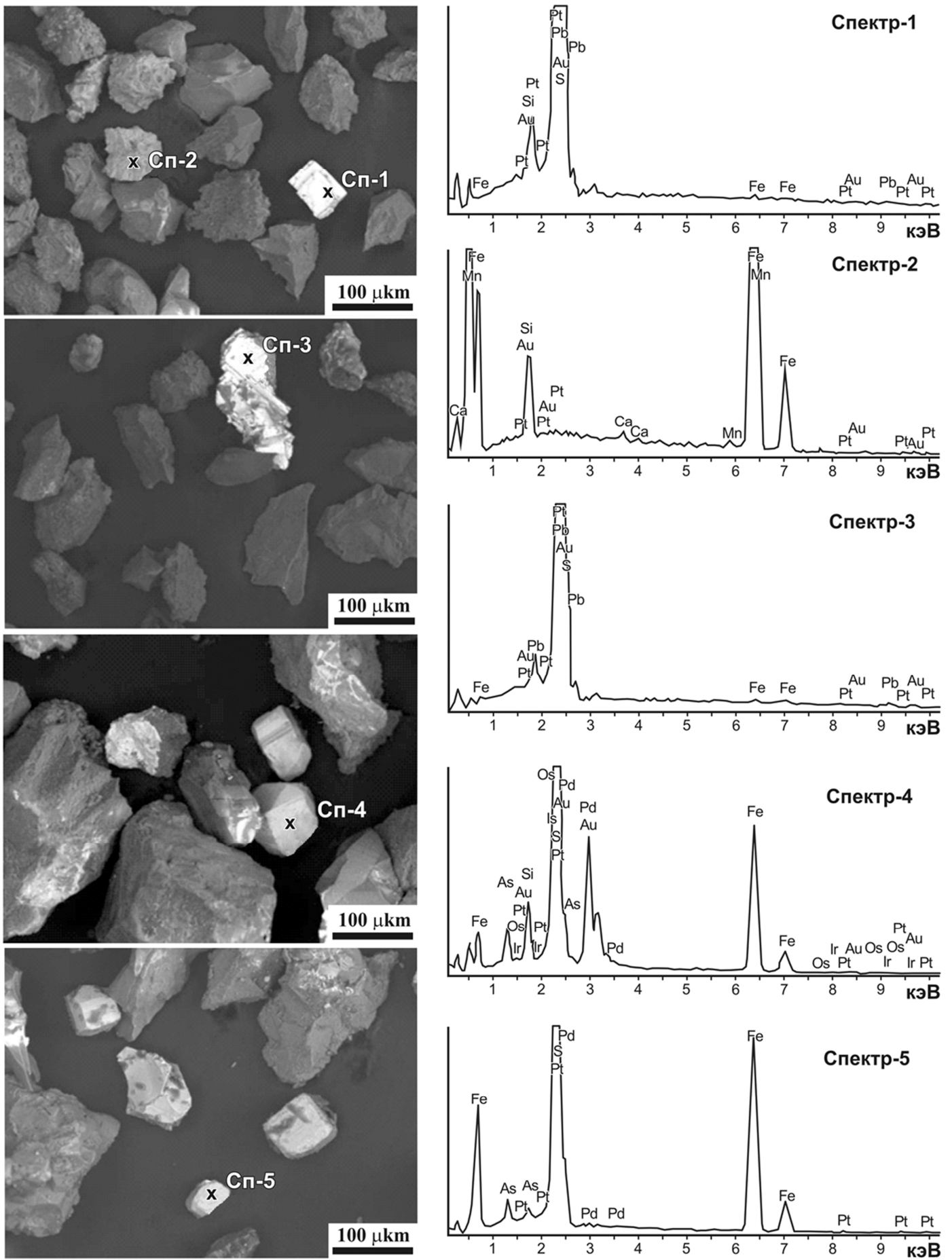

Puc. 2. Месторождение Купол. В левой части рисунка - фотографии исследуемых частиц в поле зрения микроскопа Geol 6380LW. В правой части рисунка - точечные спектры этих частиц, полученные с помощью энергодисперсионной приставки Inca.

Существующие традиционные методы аналитических исследований (в частности - пробирный метод для золота) и различные спектральные и ICP методы для платиноидов не эффективны для наноразмерных частиц этих элементов. И не только из-за отличия их физических и химических свойств от их макроразмерных аналогов, но и из-за огромного количества их возможных соединений, в том числе и металлоорга- нических, с другими элементами. Что давно известно специалистам, изучающим такие наноразмерные частицы золота и МПГ $[16,17]$.

Возможность укрупнения таких наноразмерных частиц, химический состав которых и их физические свойства не обязательно соответствуют их макроразмерным аналогам, способом «самосборки» в привычные для аналитических методов соединения, методом 

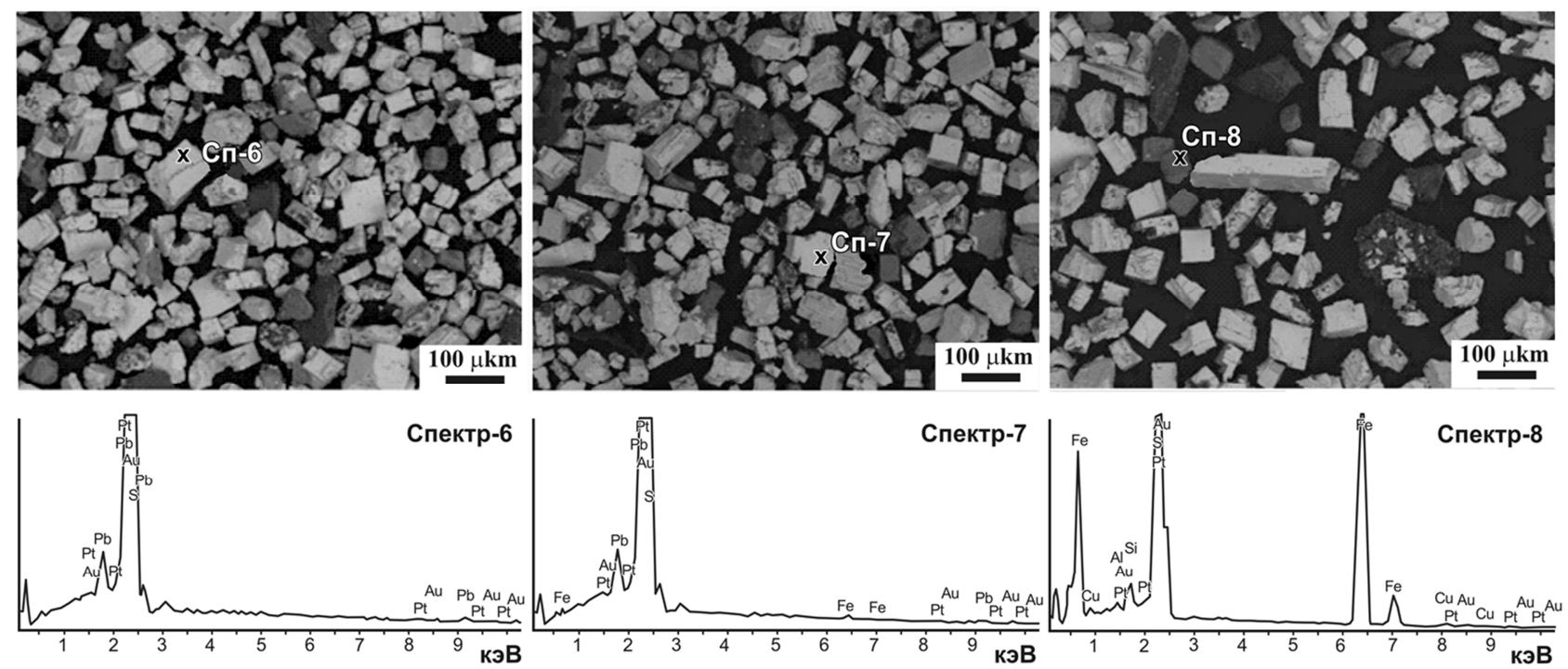

Puc. 3. Месторождение Двойное. В верхней части рисунка - фотографии исследуемых частиц в поле зрения микроскопа Geol 6380LW. В нижней части рисунка - точечные спектры этих частиц, полученные с помощью энергодисперсионной приставки Inca.
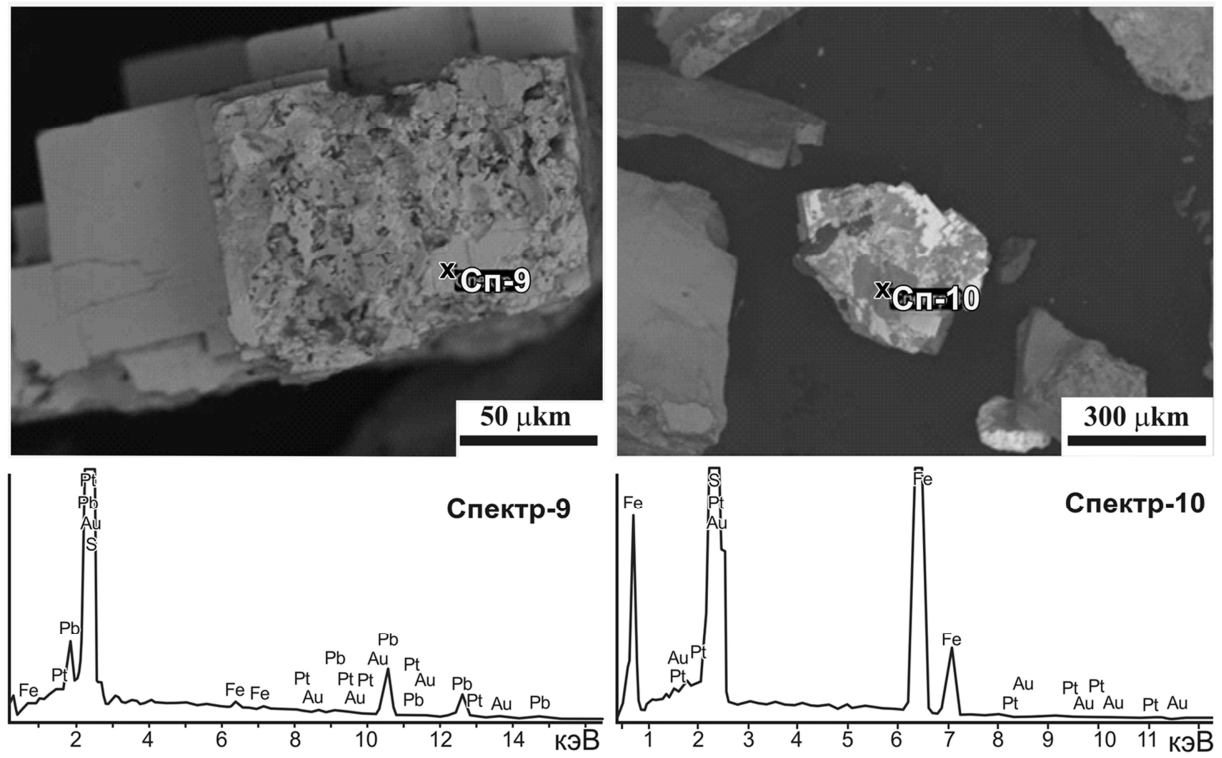

Рис. 4. Месторождение Сентябрьское. В верхней части рисунка - фотографии исследуемых частиц в поле зрения микроскопа Geol $6380 \mathrm{LW}$. В нижней части рисунка - точечные спектры этих частиц, полученные с помощью энергодисперсионной приставки Inca.

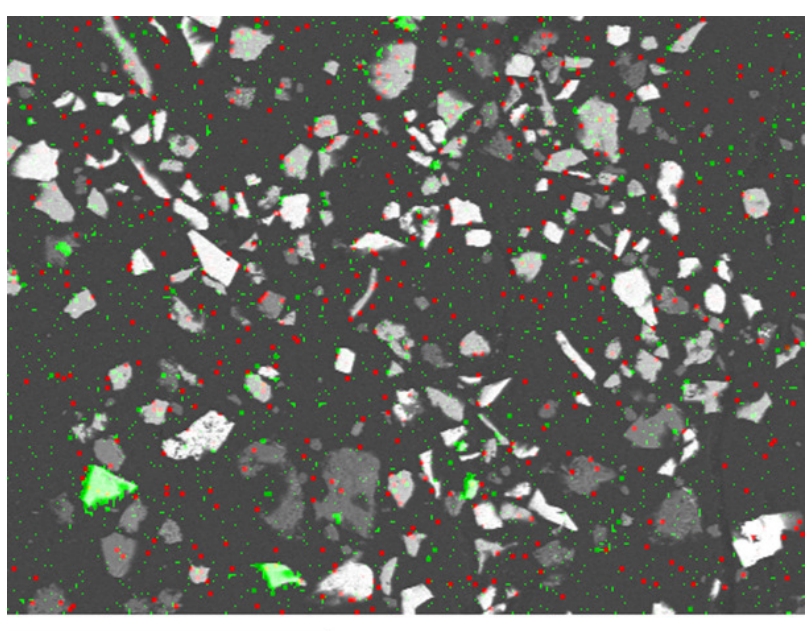

300мкm

Puc. 5. Поэлементная карта сканирования минеральных зерен тяжёлой фракции (для трёх элементов). Месторождение Купол. Растровый электронный микроскоп JSM-

6380LV JEOL с системой микроанализа INCA 250. Светло серый цвет -железо (Fe), зелёный - цирконий $(\mathrm{Zr})$, красный - платина (Pt).

Матвиенко-Калашникова [15, 18], опробованного на месторождениях Средней Азии и Приморья может дать возможность повысить извлекаемость благородных металлов. И не только для $\mathrm{Au}$ и $\mathrm{Ag}$, но и платиноидов из их наноразмерных соединений в макроформы в виде привычных «самородных» форм. В частности, это может быть справедливым и для месторождений: Купол, Двойное и Сентябрьское. Во всяком случае, это предположение требует проверки. Хотя бы на материалах хвостохранилища, куда отправляются руды с фабрики после технологического 
получения золота и серебра. В случае получения положительных результатов, это позволит пересмотреть профиль рудных объектов Чукотки, как это уже установлено в Приморье, на - золото-серебро-платиноидный.

Но уже сейчас находки платиноидов в золотосеребряных месторождениях в Сихотэ-Алинском [12, 18], а, теперь, и Охотско-Чукотском сегментах, позволяют предположить, что Чукотско-Охотско-Восточно-Сихотэ-Алинский трансрегиональный вулканоплутонический пояс является многопрофильным и заслуживает более детальных исследований на платиноиды в восточной окраине России.

\section{ЛИТЕРАТУРА}

1. Волков, А. В. Месторождение золота и серебра Чукотки / А. В. Волков, В. И. Гончаров, А. А. Сидоров. - Магадан: СВКНИИ ДВО РАН, 2006. $-221 \mathrm{c}$.

2. Рудообразование на $\mathrm{Au}-\mathrm{Ag}$ эпитермальном месторождении Купол, по данным изучения включений (Северо-Восток России) / А.В. Волков [и др.] // Геология рудных месторождений. - 2012. - Т.54. - № 4. - С. 350-359.

3. Особенности эпитермального рудообразования в Охотско-Чукотском вулкано-плутоническом поясе. / А. В. Волков [и др.] // Вулканология и сейсмология. - 2018. - №6. C. 3-22.

4. Au-Ag эпитермальное месторождение Двойное (п-ов Чукотка, Россия) / А.В. Волков [и др.] // Геология рудных месторождений. - 2019. - Т. 6. - № 6. - С. 590-609.

5. Вулканические пояса Востока Азии. Геология и металлогения / под ред. Щеглова А. Д. - М.: Наука. 1984. - 504 с. 6. Гончаров, В. И. Наталкинское золоторудное месторождение. / В. И. Гончаров, С. В. Ворошин, В. А. Сидоров. - Магадан: СВКНИИ ДВО РАН, 2002. - 229 с.

7. Глухов, А. Н. Региональная геологическая позиция, структура и минералого-геохимическая зональность золотосеребряного месторождения Купол / А. Н. Глухов //Вестник СВНЦ РАН. - 2008. - №3. - C. 34-48.

8. Региональная геолого-структурная позиция золотосеребряного месторождения Купол (Чукотка) / В.С. Кравцов [и др.] // ДАН. - 2005. - Т.404. - № 2. - С. 216-219.

9. Золото-теллуридная минерализация западной Чукотки: минералогия, геохимия и условия образования / Ю. Н. Николаев [и др.] // Геология рудных месторождений. - 2013. Т.60. - №2. - С. 114-144.

10. Пущаровский, Ю. М. Основные черты строения Тихоокеанского тектонического пояса. / Ю. М. Пущаровский // Геотектоника. - 1966. - №6. - С. 13-32.

11. Сахно, В. Г. Позднемезозойско-кайнозойский континентальный вулканизм Востока Азии. / В. Г. Сахно. - Владивосток: Дальнаука, 2001. -338 с.

12. Монцонитоидный магматизм золоторудного месторождения «Глухое»: изотопное датирование (U-Pb, SHRIMP), петро-и микроэлементный состав и особенности благородно-метальной минерализации (Приморье). / В. Г. Сахно [и др.] // ДАН. - 2015. - Т. 465. - № 3. - С. 329-337.

13. Сахно, В.Г. Геохронология и изотопно-геохимические особенности генезиса магматических комплексов золотосеребряных рудно-магматических систем чукотского сектора арктического побережья России. / В. Г. Сахно, Н. В. Григорьев, В. В. Курашко // ДАН. - 2016. - Т. 468. - № 3. - С. 297-303.

14. Сидоров, А. А. Геология и условия образования уникального золото-серебряного месторождения на Чукотке. / А. А. Сидоров, В. Ф. Белый, А. В. Волков // ДАН. - 2007. T. 412. - № 2. - C. 234-239.

15. Матвиенко, В. Н. Кластеры - протоформа нахождения драгметаллов в рудах и минерализованных породах / В. Н. Матвиенко, В. А. Калашников, В. А. Нарсеев // Руды и металлы. - 2004. - № 5. - С. 28-36.

16. Помогайло, А. Д. Полимер-иммобилизованные наноразмерные и кластерные частицы металлов. / А. Д. Помогайло // Успехи химии. - 1997. - Т. 66. - Вып. 8. - С. 750-791.

17. Помогайло, А. Д. Наночастицы металлов в полимерах. / А. Д. Помогайло, А. С. Розенберг, И. Е. Уфлянд. - М.: Химия, 2000. $-672 \mathrm{c}$.

18. Самосборка нанодисперсных форм платиноидов как метод их извлечения на примере золотосеребряных руд Милоградовского проявления / Е. В. Ненахова [и др.]. // Вестник Воронеж. гос. ун-та. Сер.: Геология. - 2018. - № 4. - C. $102-106$

RAS Far eastern branch Far East Geological Institute, Vladivostok

Sahno V. G., Doctor of Geological and Mineralogical Sciences, Professor, corresponding member of RAS

E-mail:v_sakhno@mail.ru

Tel.: +7 (423) 2320560

PrimorZoloto CJSC, Moscow

Kuznetsov Yu. A., chief geologist

E-mail: tundra49@mail.ru

Federal State Budgetary Institution «All-Russian Research Geological Oil Institute», Moscow

Dubkov A. A., geologist

E-mail:dubston@mail.ru

Citrin LLC, Voronezh

Nenakhova E.V., lead geologist

E-mail: evnenakhova@mail.ru 